University of Wollongong

Research Online

Faculty of Social Sciences - Papers (Archive) Faculty of Arts, Social Sciences \& Humanities

2015

Place stigma as boundary-making from the outside in: the case of Cronulla

Natascha Klocker

University of Wollongong, natascha@uow.edu.au

Follow this and additional works at: https://ro.uow.edu.au/sspapers

Part of the Education Commons, and the Social and Behavioral Sciences Commons

Research Online is the open access institutional repository for the University of Wollongong. For further information contact the UOW Library: research-pubs@uow.edu.au 


\title{
Place stigma as boundary-making from the outside in: the case of Cronulla
}

\author{
Abstract \\ 'But she's brown', says the little girl in the rock pool, glancing at my daughter. 'Yes she is'. The girl is \\ persistent: 'Why?" Because her daddy is brown'. A lightbulb moment (my daughter and I suddenly 'make \\ sense', together), a smile and an invitation: 'She can play with my body board'. A surfer-wetsuit folded \\ down, a heavily tattooed torso-strides with purpose towards a Tanzanian man and his daughter, playing at \\ Cronulla Beach. 'I see you here a lot'. This sentence is thrown forth in a gruff tone. My husband's mind \\ starts hatching plans to keep our little girl safe, should this situation get ugly. 'Yes, we come down here \\ most days, when it's warm'. The surfer smiles, 'That's great'.

\section{Keywords} \\ case, place, cronulla, stigma, boundary, making, outside \\ Disciplines \\ Education | Social and Behavioral Sciences

\section{Publication Details} \\ Klocker, N. (2015). Place stigma as boundary-making from the outside in: the case of Cronulla. Australian \\ Geographer, 46 (4), 421-427.
}


Klocker, N. (2015) 'Place stigma as boundary-making from the outside in: the case of Cronulla' Australian Geographer 46 (4), 421-427.

Dr Natascha Klocker

Australian Centre for Cultural Environmental Research (AUSCCER)

Department of Geography and Sustainable Communities

University of Wollongong

natascha_klocker@uow.edu.au

\section{Cronulla beach moments}

'But she's brown', says the little girl in the rock pool, glancing at my daughter. 'Yes she is'. The girl is persistent: 'Why?' 'Because her daddy is brown'. A lightbulb moment (my daughter and I suddenly 'make sense', together), a smile and an invitation: 'She can play with my body board'.

A surfer - wetsuit folded down, a heavily tattooed torso - strides with purpose towards a Tanzanian man and his daughter, playing at Cronulla Beach. 'I see you here a lot'. This sentence is thrown forth in a gruff tone. My husband's mind starts hatching plans to keep our little girl safe, should this situation get ugly. 'Yes, we come down here most days, when it's warm'. The surfer smiles, 'That's great'.

On December 11, 2005 - while I was living half a world away in Tanzania - a crowd of approximately 5000 mostly 'white' youths attacked people of 'Middle Eastern appearance' in areas around Cronulla Beach, the local shops and the railway station. The rioters were drawn to Cronulla, from across Sydney, by text messages that sought to incite violence and to reaffirm ownership of the national/local space. Attacks and counter-attacks continued in Cronulla, and other parts of Sydney, over subsequent days. 
Cronulla is my home. I grew up here. I am white, but not Anglo-Australian. My family migrated to Australia from Austria when I was a baby. Since 2010, I have lived in Cronulla with my husband and daughters. We live only a few hundred metres from the places where the riots broke out, and we are very regular visitors to Cronulla Beach. Because my children are of mixed Austrian-Tanzanian heritage, my understanding of my own whiteness and white privilege is contingent, complicated and unsettled. The 'invisible knapsack...of unearned assets' (McIntosh 2015, p. 74) that I carry around as a white person, has become more apparent. It is heavy, uncomfortable and unfair. My experiences of Cronulla (and indeed, of Sydney more generally) have shifted - both fundamentally, and in nuanced ways that depend upon which family members I am walking with. Nonetheless, when I use the term 'well-intentioned white people' throughout this essay, I understand that I am part of this group.

I have not written about the Cronulla riots before. I am not sure why that is, especially given my research interest in ethnic diversity and racism. Perhaps I didn't need to - after all, many academics have contributed important perspectives on the matter (see Poynting 2006; Colishaw 2007; Collins 2007; Lattas 2007a, 2007b; Dunn 2009; Noble 2009; Shaw 2009; Noble and Poynting 2010; Nelson 2014). But now, ten years on, there is something that I want to say. I am concerned that 'we' (wellintentioned white people) have co-produced a problem. 'White 'evil' nationalists' ${ }^{1}$ (Hage 1998) seek to undermine the spatial belonging of 'Others'. I worry that we have been doing their job for them. Place stigma has had a perverse outcome in the case of Cronulla: it has bolstered white privilege and further inhibited the geographies of ethnic and religious minorities.

\footnotetext{
${ }^{1}$ I am informed, in this essay, by Ghassan Hage's (1998) categories: 'Good White nationalists' and 'White 'evil' nationalists'.
} 


\section{On place stigma}

Stigma causes people to be 'disqualified from full social acceptance' due to attributes that others find 'deeply discrediting' (Goffman 1963, p. 9). Place or neighbourhood stigma - which disqualifies individuals on the basis of their residential location - is typically targeted at areas of socioeconomic disadvantage (Gibson 2013). This is the 'blemish of place' (Wacquant 2007; Pearce 2012). For Morris (2009, p. 1), stigma and stereotype 'are forms of apprehension rather than bad representations, and their force is to mobilize familiar knowledge to explain and absorb unfamiliar experience' (emphasis in original). Place stigma, then, seeks to render unfamiliar places apprehensible (knowable) to outsiders, by making outsiders apprehensive of them. 'Territorial stigmatisation' (Wacquant 2007) creates a cognitive map of acceptable and unacceptable localities (Takahashi 1997), with harmful implications for residents of the latter. In Victoria, Kelaher et al. (201, p. 381) found that stigmatised residential identities adversely affect the opportunities afforded to residents, and their health outcomes (see also Gourlay 2006; Pearce 2012).

Cronulla is a stigmatised place. A recent content analysis of media representations and survey responses demonstrated empirically that residents of Cronulla and the Sutherland Shire - the broader Local Government Area (LGA) of which it is part - are regularly and widely derided as white, insular, racist, bogan ${ }^{2}$ and uneducated (Norquay 2014; Norquay and Drozdzewski, under review). My purpose here is not to debate the veracity of these stereotypes, nor to engage in placedefending - although I do find the 'white' stereotype particularly irksome because it renders threequarters of my family invisible from the imaginary of this place ${ }^{3}$. Place-defending occurs when local

\footnotetext{
${ }^{2}$ Gibson (2013, p. 62) has defined bogan as 'a term of derision with some parallel to white trash in the United States and chav in the United Kingdom, used mockingly to describe people of working-class origin, people considered "rough" and uncultured'.

${ }^{3}$ Rural geographers have contributed important perspectives on this matter. They have insisted on greater recognition of the multicultural nature of stereotypically 'white' places (like rural England and Australia), to avoid marginalising the lives and experiences of ethnic minority people who live there (Askins 2009; Panelli et al. 2009).
} 
actors seek to protect their areas from the blemish of place (Nelson 2014). In the case of purportedly racist places, it operates by denying racism - in one (or more) of the following ways:

absence discourses, which posit simply that there is no racism; temporal deflections, whereby a passage of time separates a person or place from racism; deflections from the mainstream, by which 'pockets' of racist issues are acknowledged, but structural or systemic racism is denied; and...spatial deflections, whereby one claims an absence of racism in a particular locality or place (Nelson 2014, p. 73).

I am acutely aware - through my academic work and through the experiences of my own mixedethnicity family - that racism is prevalent and harmful in Australia. Cronulla is no exception. But in this essay I want to consider the implications of Cronulla's stigmatisation.

While some residents of the Sutherland Shire feel frustrated and uncomfortable with media representations and public discourses that surround their local area (Norquay 2014), those who perpetuate these stereotypes appear to have missed their mark. The stigma surrounding Cronulla has not dampened the socio-economic prospects of its residents. It does not appear to have limited their life chances. Data from the 2011 Australian Census of Population and Housing indicate that Sutherland Shire LGA performs well on a range of socio-economic indicators. The area has an unemployment rate of 3.5 per cent (compared to 5.6\% Australia-wide); and a median weekly family income of AUD 2014 (AUD 533 above the national average) (ABS 2013). The area's residents have rates of tertiary education on par with the national average ( $14.5 \%$ and $14.3 \%$ respectively) and the dominant occupational category in the area is 'professionals' $(23.0 \%$ compared to $21.3 \%$ Australiawide) (ABS 2013). More than three-quarters (76.5\%) of Sutherland Shire residents own their own homes (either outright or with a mortgage), compared to a national average of 67.0 per cent 
(ABS2013). Property in the Sutherland Shire is in demand - the median house price in the 12 months to 2015 was AUD 1,553,000 (Domain, 2015). Despite the negative stereotypes, this is a place where Sydneysiders want to live.

These outcomes suggest that the type of place stigma that surrounds Cronulla (and the Sutherland Shire more broadly) differs from that which is directed towards areas of existing socio-economic disadvantage. In such places, stigma has been shown to contribute to a decline in service provision and inward local investment. Some residents of stigmatised neighbourhoods face challenges in gaining employment - the address written on a CV matters (Gourlay 2007). Place stigma acts to keep people 'in their place' (Kelaher et al. 2010, p. 386). Cronulla residents, on the contrary, seem to be doing just fine. On the surface, those who joke and circulate negative stereotypes about the area are committing a victimless crime. This is a comfortable delusion. In this essay I argue that the stigmatisation of Cronulla has very real and important implications.

\section{Boundary-making (from the outside in)}

The negative stereotypes that circulate about Cronulla have arguably had a greater effect on ethnic and religious minorities than on stigmatised white 'locals'. The Cronulla riots had a boundarymaking intent - and effect (Dunn 2009; Noble and Poynting 2010; Itaoui 2014; Nelson 2014). The events of December 2005 were a particularly 'intense moment of ethnic 'purification" (Noble and Poynting 2010, p. 499). The riots were a performance of Australian nationalism and white privilege (Dunn 2009) that sought to affirm spatial racial boundaries. The stereotypes that have surrounded Cronulla and the Sutherland Shire over the ensuing decade have bolstered these walls, from the outside in. A recent study of the geographies of young Muslims in Sydney revealed that many are hesitant to visit the Sutherland Shire (Itaoui 2014; see also Noble and Poynting 2010). Media coverage of Cronulla featured heavily in young Muslims' explanations for avoiding this place, 
prompting Itaoui (2014) to conclude that media reporting of the Cronulla riots reproduced the ethnic purification tactics of the rioters (see also Sibley 1995).

Belonging and social exclusion are fundamentally spatial processes - most evident in overtly hostile, violent and racist encounters such as the Cronulla riots (Noble and Poynting 2010). But spatial racial boundaries are also established and maintained in a myriad of subtle ways (Hage 1998). Noble and Poynting (2010, p. 495) have referred to a 'pedagogy of unbelonging', which teaches ethnic and religious minorities 'to feel less comfortable in certain neighbourhoods and the wider national space simultaneously'. As Hage (1998) has made so abundantly clear, spatial racial boundaries are perpetuated in obvious ways by 'White 'evil' nationalists'; but are simultaneously enacted by 'Good White nationalists'. Both of these groups inhabit 'the same imaginary position of power within a nation imagined as 'theirs" (Hage 1998, p. 79). Ethnic and religious minorities are effectively 'caged' by good and evil white nationalists alike (Hage 1998, p. 45).

The boundary-making (from the outside in) that has occurred in relation to Cronulla, is often enacted in quotidian moments - what I like to call: 'dinner party moments with well-intentioned white people'. These moments typically take place somewhere on the other side of Captain Cook Bridge $^{4}$, in parts of Sydney known for their progressive politics. In these moments, 'uncaged ethnics ${ }^{5}$ (like my husband and children) are a source of consternation. When meeting new people, across the bridge, the revelation that we live in Cronulla is typically met with a befuddled expression, a raised eyebrow. We have had people ask us why we live in Cronulla (with the sub-text being - there are brown people in your family, why are you living in a white place?) My family is confusing for well-intentioned white people because we appear to have lost our cognitive map.

\footnotetext{
${ }^{4}$ Captain Cook Bridge is one of two bridges crossing Sydney's Georges River, providing an entryway to the Sutherland Shire. It is a common joke - usually made by people who live outside the Sutherland Shire - that you need a visa and passport to get in (Verghis 2002).

II have borrowed here from Hage's (1998, p. 45) observation that 'the 'ethnic' is...a being which is 'caged', not someone who can easily claim the position of managing the field'.
} 
Surely we would be much more comfortable in other parts of Sydney. People are generally too polite to go further. But, occasionally, the Cronulla jokes come out. These are typically addressed towards my husband (the person in our family who is most visibly different from the stereotype of white Cronulla): ‘But you don't look like a bogan!' Through showing disdain for Cronulla - and confusion when confronted with my family's presence there - I can only assume that our dinner party companions are attempting to 'disaffiliate' themselves from the types of obvious racism that they associate with the area (Wiegman 1999; Berg 2012, p. 509). Perhaps these encounters are also an example of what Berg (2012, p. 512) has referred to as 'white rescue fantasies'. Read: if you lived in our diverse/anti-racist/liberal/educated/progressive neighbourhood we would be nice to you. But the effect of these encounters is nefarious. White privilege is operational in these moments, in which well-intentioned white people articulate their own sets of spatial racial (and classed) boundaries. While their politics are diametrically opposed, 'White 'evil' nationalists' and 'Good White nationalists' are participating in the same process: making brown people feel uncomfortable in white places. Through such moments, well-intentioned white people - while actively asserting their own anti-racist identities - are participants in 'sociospatial relations of white supremacy' (Berg 2012, p. 513).

\section{Being actively quiet?}

Discursive attempts to ridicule and punish (white/racist/bogan/insular/uneducated) Cronulla residents have bolstered the very exclusionary tendencies that they seek to critique. We need to reflect carefully on who is being harmed by the prevalent stereotypes of this place - and other neighbourhoods that are similarly stigmatised. It is time to interrupt this cycle, although not by denying racism or defending the indefensible (wherever it occurs). Well-intentioned white people have a role to play in challenging stereotypes that attach geographical limitations to brown skin, to religious clothing. My children should not have to feel limited to particular spatial racial containers 
- to gilded, progressive, liberal cages - no matter the intentions of the people who put them there. But spatial racial boundaries can only be unsettled with commitment from both sides - in this case, those who live in Cronulla, and those who view it from the outside in. I don't plan to write about Cronulla again - until I have something to say that's not about the 2005 riots. I invite others to join me.

\section{Acknowledgements}

Thank you to Paul Mbenna for contributing ideas to this essay, and for allowing me to write so openly about our family; and to Chris Gibson for the invitation to write this piece. My appreciation also goes to Chantel Carr and Ananth Gopal for commenting on a draft of this manuscript, and to Danielle Drozdzewski and Melinda Norquay for giving me access to their 'under review' manuscript about Cronulla.

\section{References}

ASKINS, K. (2009) 'Crossing divides: ethnicity and rurality', Journal of Rural Studies, 25(4), pp. 365375.

AUSTRALIAN BUREAU OF STATISTICS (ABS) (2013), Sutherland Shire (LGA): Basic Community Profile, 2011 Census Community Profiles, Australian Bureau of Statistics, Canberra.

BERG, L. (2012) 'Geography -- (neo)liberalism -- white supremacy." Progress in Human Geography, 36(4), pp. 508-517.

COLISHAW, G. (2007) 'Introduction: ethnography and the interpretation of 'Cronulla", The Australian Journal of Anthropology, 18(3), pp. 295-299.

COLLINS, J. (2007) 'The landmark of Cronulla' in Jupp, J. and Nieuwenhuys, J. (eds) Social Cohesion in Australia, Cambridge University Press, Cambridge, pp. 61-69. 
DOMAIN (2015) ‘Property Research Report for Cronulla, 2230’, http://www.domain.com.au/apm/Research/?AddressLine=cronulla\%20NSW\&LocationType=Suburb \&State=NSW\&Suburbld=12262, accessed 24.7.15.

DUNN, K. (2009) 'Performing Australian nationalisms at Cronulla', in Noble, G. (ed) Lines in the Sand: the Cronulla Riots, multiculturalism and national belonging, Sydney Institute of Criminology/The Federation Press, Sydney, pp. 76-94.

GIBSON, C. (2013) 'Welcome to Bogan-ville: reframing class and place through humour', Journal of Australian Studies, 37(1), pp. 62-75.

GOFFMAN, E. (1963) Stigma. Notes on the Management of Spoiled Identity. Penguin, Harmondsworth.

GOURLAY, G. (2006) Neighbourhood stigma and social exclusion: the case of two Scottish peripheral estates. PhD thesis, University of Glasgow.

GOURLAY, G. (2007) 'It's got a bad name and it sticks...' Approaching stigma as a distinct focus of neighbourhood regeneration initiatives', Paper presented at the EURA Conference, 'The Vital City', 12-14 September 2007, Glasgow.

HAGE, G. (1998) White nation: fantasies of white supremacy in a multicultural society, Pluto Press, Sydney.

ITAOUI, R. (2014) Experiences of Islamophobia: effects on the mobility of young Muslims living in Sydney. Honours Thesis, University of Western Sydney.

KELAHER, M., WARR, M., FELDMAN, P., TACTICOS, T. (2012) 'Living in 'Birdsville': Exploring the impact of neighbourhood stigma on health', Health \& Place, 116: 381-388.

LATTAS, A. (2007a) 'They always seem to be angry': The Cronulla riot and the civilising pleasures of the sun', The Australian Journal of Anthropology, 18(3), pp. 300-319.

LATTAS, J. (2007b) 'Cruising: 'moral panic' and the Cronulla riot', The Australian Journal of Anthropology, 18(3), pp. 320-335. 
MCINTOSH, P. (2015) 'White privilege: unpacking the invisible knapsack', in Andersen, M. and Collins, P. (eds) Race, Class \& Gender: An anthology $9^{\text {th }}$ Edition, Cengage Learning, Boston, pp. 7483.

MORRIS, M. (2009) 'Grizzling about facebook', Australian Humanities Review 47, http://www.australianhumanitiesreview.org/archive/Issue-November-2009/morris.html (accessed 27.7.15)

NELSON, J. (2014) 'Place-defending and the denial of racism' Australian Journal of Social Issues, 49(1), pp. 67-85.

NOBLE, G. (2009) Lines in the Sand: the Cronulla Riots, multiculturalism and national belonging, Sydney Institute of Criminology/The Federation Press, Sydney.

NOBLE, G., AND POYNTING, S. (2010) 'White Lines: The Intercultural Politics of Everyday Movement in Social Spaces', Journal of Intercultural Studies 31(5), PP. 489-505.

NORQUAY, M. (2014) Stereotyping the Shire: How media construct place and identity and influences public opinion. Honours Thesis, University of New South Wales.

NORQUAY, M. AND DROZDZEWSKI, D. (under review) 'Stereotyping the Shire: assigning white privilege to place and identity', Social \& Cultural Geography.

PANELLI, R., HUBBARD, P., COOMBES, B. AND SUCHET-PEARSON, S. (2009) ‘De-centring White ruralities: ethnic diversity, racialisation and Indigenous countrysides' Journal of Rural Studies, 25(4), pp. 355-364.

PEARCE J. (2012)' 'The 'blemish of place': Stigma, geography and health inequalities. A commentary on Tabuchi, Fukuhara \& Iso' Social Science \& Medicine, 75(11), pp. 1921-1924. POYNTING, S. (2006) 'What caused the Cronulla Riot?' Race \& Class 48(1), pp. 85-92. SHAW, S. (2009) 'Riotous Sydney take three (Cronulla): Confessions of a beach survivor', in Noble, G. (ed) Lines in the Sand: the Cronulla Riots, multiculturalism and national belonging, Sydney Institute of Criminology/The Federation Press, Sydney, pp. 58-71. 
SIBLEY, D. (1995) Geographies of exclusion. Routledge, London.

TAKAHASHI, L. (1997) 'The socio-spatial stigmatization of homelessness and HIV/AIDS: toward an explanation of the NIMBY syndrome', Social Science and Medicine, 45(6), pp. 903-914. VERGHIS, S., (2002) 'Southern crossings', Sydney Morning Herald, 9.1.02.

WACQUANT, L. (2007). 'Territorial stigmatization in the age of advanced marginality', Thesis Eleven, 91(1), pp. 66-77.

WARR, D. (2006) 'There goes the neighbourhood: the malign effects of stigma', Refereed Proceedings of the 2nd Bi-annual National Conference on the State of Australian Cities, 2006. WIEGMAN, R. (1999) 'Whiteness studies and the paradox of particularity', Boundary 2 26(3), pp. 115-150. 